\title{
Peningkatan Kesadaran Demokrasi dalam Organisasi Badan Eksekutif Mahasiswa Universitas Pasir Pengaraian
}

\author{
Ryan Prayogi \\ Fakultas Keguruan Ilmu Pendidikan, Universitas Pasir Pengaraian, Indonesia
}

Diterima: Oktober 2018; Disetujui: Oktober 2018; Dipublish: Oktober 2018

E-mail: ryan.prayogi888@gmail.com

\begin{abstract}
Abstrak
Penelitian ini dilatarbelakangi rendahnya kesadaran demokrasi mahasiswa khususnya Badan Eksekutif Mahasiswa Universitas Pasir Pengaraian dalam mengikuti berbagai kegiatan yang dilakukan di kampus maka dari itu perlu dilakukan peningkatan kesadaran demokrasi mahasiswa melalui Pendidikan Kewarganegaran sebagai domain sosial kultural yang merupakan gerakan civil society. Penelitian ini bertujuan (1). Untuk mengetahui kondisi kesadaran demokrasi dalam Organisasi Badan Eksekutif Mahasiswa (BEM) Universitas Pasir Pengaraian (2). Untuk mengetahui proses peningkatan kesadaran demokrasi dalam Organisasi Badan Eksekutif Mahasiswa (BEM) Universitas Pasir Pengaraian. Penelitian ini menggunakan pendekatan kualitatif dengan metode studi kasus. Teknik pengumpulan data dan informasi dilakukan melalui teknik observasi, wawancara dan studi dokumentasi. Hasil penelitian ini yaitu: (1). Kondisi kesadaran demokrasi Badan Eksekutif Mahasiswa Universitas Pasir Pengaraian meliputi: kebebasan dalam berorganisasi dan terjalinnya kerjasama, kesempatan dalam mengemukakan pendapat, rasa saling percaya dan sikap saling menghargai, dan memiliki prinsip persamaan kedudukan didalam organisasi. (2). Peningkatan kesadaran demokrasi mahasiswa di Badan Eksekutif Mahasiswa Universitas Pasir Pengaraian meliputi: Penerapan pendekatan persuasif, melakukan kegiatan penalaran, pelatihan kepemimpinan dan pengkaderan serta efektifitas kegiatan yang dilakukan oleh Badan Eksekutif Mahasiswa dalam peningkatan kesadaran demokrasi mampu kinerja pengurus BEM Universitas Pasir Pengaraian.
\end{abstract}

Kata Kunci: Kesadaran Demokrasi, Organisasi Mahasiswa, Pendidikan Kewarganegaraan.

\begin{abstract}
This research is motivated by the low level of student's democratic awareness, especially the Pasir Pengaraian University Student Executive Board in participating in various activities carried out on campus, therefore it is necessary to increase students' democratic awareness through Citizenship Education as a social cultural domain which is a civil society movement. This study aims (1). To find out the condition of democratic awareness in the Pasir Pengaraian University Student Executive Board (BEM) Organization (2). To find out the process of increasing democratic awareness in the Pasir Pengaraian University Student Executive Board (BEM) Organization. This study uses a qualitative approach to the case study method. Data and information collection techniques are carried out through observation, interviews and documentation studies. The results of this study are: (1). Conditions of democratic awareness of the Pasir Pengaraian University Student Executive Board include: freedom of organization and the establishment of cooperation, opportunities in expressing opinions, mutual trust and mutual respect, and having equality in the organization. (2). Student democracy awareness raising at Pasir Pengaraian University Student Executive Board includes: Application of persuasive approach, conducting reasoning activities, leadership and cadre training and effectiveness of activities carried out by the Student Executive Board in enhancing democratic awareness capable of the performance of the Pasir Pengaraian University BEM board.
\end{abstract}

\section{Keywords: Democratic Awareness, Student Organizations, Citizenship Education.}

How to Cite: Prayogi. R. (2018). Peningkatan Kesadaran Demokrasi dalam Organisasi Badan Eksekutif Mahasiswa Universitas Pasir Pengaraian. Journal of Education, Humaniora and Social Sciences (JEHSS). 1 (1): 55-62.

\section{PENDAHULUAN}

Pada era globalisasi dewasa ini, mengalami perubahan yang berlangsung begitu cepat dan munculnya berbagai tantangan bagi bangsa Indonesia. Perubahan tersebut meliputi perubahan tatanan sosial, politik ekonomi, pertahanan negara dan lain sebagainya sebagai akibat kemajuan ilmu pengetahuan dan teknologi akibat dari globalisasi. Globalisasi merupakan proses yang terus bergerak memasuki ranahranah yang tak pernah terbayangkan sebelumnya sehingga mobilitas begitu cepat dan masif. Konsekuensinya adalah warga negara muda tidak bisa mengisolasi diri dari globalisasi dan harus memiliki wawasan global. Dengan demikian seyogyanya perlu pembentukan warga negara berwawasan global (global citizen). Noddings (Rapoport, 2008) mengatakan bahwa "a global citizen is one who can live and 
work effectively anywhere th the world, supported by a global way of life". Dari paparan di atas penekanannya ada pada eksistensi warga negara dalam konteks kehidupan global.

Masalah utama yang sangat dirasakan oleh bangsa Indonesia dalam menghadapi era global ini adalah keterbatasan sumber daya manusia yang berkualitas untuk berpartisipasi dan berperan aktif dalam penyelenggaraan pembangunan, baik dalam lingkup nasional ataupun internasional. Untuk mengatasi masalah dampak dari globalisasi diperlukan peran pemuda dan mahasiswa yang dianggap penting menjadi peran sentral sebagai sosok pemuda yang harus siap dan tanggap dalam memberikan kontribusinya sebagai Agent of change atau pembawa perubahan. Dalam sejarah menunjukkan bahwa peran pemuda dan mahasiswa selalu menjadi bagian dari pilar demokrasi, sebagai pelopor, penggerak, bahkan pengambil keputusan. Hal ini dibuktikan pada era Sumpah Pemuda 1928, pergerakan 1945, angkatan 1966 yang membidani Tritura, Malari 1974, 1978, dan Reformasi 1998. Namun dengan adanya perkembangan politik yang dilatarbelakangi demokrasi sebagai sistem politik, peran pemuda dan mahasiswa mulai dhadapkan pada persimpangan pemikiran dan gerakan, sehingga tujuan untuk membangun perubahan ke situasi yang lebih baik justru yang terjadi sebaliknya. Berbagai aksi demonstrasi yang diangggap suatu bentuk gerakan yang dilakukan mahasiswa akhir-akhir ini sebagai wujud kritik terhadap pemerintahan mulai mengalami kemorosotan kepercayaan dari masyarakat, bahkan aksi demonstrasi seringkali disinyalir sudah dikooptasi oleh kepentingan-kepentingan elit yang berkuasa. Oleh sebab itu peran pemuda dan mahasiswa berkontribusi mencegah dampak negatif globalisasi melalui sebuah organisasi kepemudaan dan mahasiswa.

Menurut Muhamad (2000) mengungkapkan bahwa organisasi adalah suatu koordinasi rasional kegiatan sejumlah orang untuk mencapai beberapa tujuan umum melalui pembagian pekerjaan dan fungsi melalui hierarki otoritas dan tanggung jawab. Berdasarkan teori diatas maka dapat disimpukan bahwa organisasi merupakan suatu kelompok yang terdiri dari beberapa individu yang saling berinteraksi dan mempegaruhi untuk mencapai suatu tujuan. Organisasi mahasiswa merupakan sekumpulan mahasiswa yang membentuk sebuah kelompok untuk mencapai tujuan bersama. Sejalan dengan Kepmendikbud.155/U/1998 tentang pedoman organisasi mahasiswa dalam perguruan tinggi dalam keputusan ini yang dimaksud dengan Organisasi kemahasiswaan intra perguruan tinggi adalah wahana dan sarana pengembangan diri mahasiswa kearah perluasan wawasan dan peningkatan kecendekiawanan serta integritas kepribadian untuk mencapai tujuan pendidikan tinggi.

Melalui pendidikan kewarganegaraan sebagai kajian ilmu kependidikan yang memusatkan perhatian pada pengembangan warga negara yang cerdas, demokratis dan religius serta memiliki karakteristik yang multidimensional. Disamping itu, PKn sebagai salah satu mata pelajaran yang diajarkan disemua jenjang dan jenis sekolah secara pragramatik memiliki Psyco-Pedagogis, yaitu membina warganegara yang demokratis dalam ruang lingkup pendidikan di lembaga pendidikan fomal maupun formal. Sapriya dan Winataputra (2010) menyatakan bahwa tugas PKn dengan paradigma barunya mengembangkan pendidikan demokrasi mengembangkan tiga fungsi pokok, yakni mengembangkan kecerdasan warganegara (Civic Intelegence), membina tanggungjawab warganegara (Civic Responsibility) dan mendorong partisipasi warganegara (Civic Participations). Sehingga kedudukan Pendidikan Kewarganegaraan dalam kontek demokrasi sangat penting bagi generasi muda untuk mewarisi pengetahuan, keterampilan dan memiliki karakter kepribadian menjadi warga negara yang baik (Good Citizenship).

Kesadaran merupakan sikap dan perilaku seseorang dalam mengetahui atau mengerti terhadap sebuah aturan dan memiliki ketaatan terhadap ketentuan perundang-undangan. Sementara itu, Fraenkel (1940) dalam Djahiri (1985) dalam Candra (2011) mengatakan kesadaran adalah suatu tingkat kesiagaan individu pada saat ini stimulus internal dan eksternal, terhadap peristiwa dilingkungan dan sensasi tubuh, memori dan fikiran. Jadi dapat diambil kesimpulan bahwa kesadaran demokrasi merupakan sikap dari kepribadian yang tumbuh dari rasa tanggung jawab yang menitikberatkan pada kesadaran moral dan religius dalam bertindak sesuai perundang-udangan atau aturan hukum yang berlaku. Oleh sebab itu, mahasiswa hendaknya tampil sebagai kekuasaan moral (Moral Force) yang menyuarakan hati nurani masyarakat (Social Conscience) bukan hanya citra sebagai demonstran yang menyuarakan sikap tidak setuju dan menetang tanpa menawarkan alternatif pemecahannya.

Permasalahan yang dihadapi saat ini adalah belum adanya keterpaduan antara kegiatan kurikuler dengan kegiatan ekstrakurikuler yang di miliki mahasiswa, disatu sisi masih sangat sedikit mahasiswa yang berminat pada program pengembangan penalaran dan kelimuan; bakat, minat, dan kemampuan; kesejahteraan; kepedulian sosial; dan kegiatan penunjang. Sedangkan mahasiswa yang berpartisipasi dalam organisasi mahasisswa intra perguruan tinggi jumlahnya relatif kecil, akan tetapi ketika dilandasi kepentingan yang ada di luar dari kepentingan mahasiswa bahkan menyuarakan aspirasi kelompok, 
ideology tertentu, bahkan bernuansa kepentingan partai politik dan elit politik tertentu. Adapun gerakan kepentingan organisasi intra kampus cenderung diinfiltrasi oleh kepentingan organisasi ekstra yang memunculkan konflik antar mahasiswa dalam merebutkan kader. Proses ini mudah terlihat ketika terjadi pemilihan Presiden BEM, Gubernur BEM, Bupati HIMA Program Studi dimana cenderung konflik yang dipengaruhi kepentingan kelompok menjadi tema penting diantara mahasiswa. Keadaan ini justru menjerumuskan mahasiswa kedalam gerakan yang terpecah belah dan cenderung mengabaikan kepentingan rakyat. Oleh karena itu, Organisasi kampus mengimplementasikan kesadaran demokrasi melalui kegiatan-kegiatan pemilihan Presiden Badan Eksekutif Mahasiswa (BEM) dengan tidak melakukan aksi yang radikal dan sporadis dan mengedepankan sisi akademis dan kompromi. Masalah pembinaan organisasi mahasiswa menurut peneliti merupakan bagian dari pendidikan kewarganegaraan dalam meningkatkan kualitas warganegara muda yang cerdas, demokratis, dan religius. Pemuda secara mutlak bertanggungjawab terhadap bangsa dan negara Indonesia dalam proses demokrasi, dengan membangkitkan semangat kepedulian terhadap masalah sosial yang merupakan salah satu tugas PKn, khususnya PKn sebagai domain sosialkultural atau Pendidikan Kewarganegaraan di masyarakat (Community Civics). Atas pemikiran tersebut maka peneliti tertarik untuk melakukan penelitian mengenai peningkatan kesadaran demokrasi dalam organisasi Badan Eksekutif Mahasiswa Universitas Pasir Pengaraian.

\section{METODE PENELITIAN \\ Desain Penelitian}

Desain penelitian yang digunakan dalam pemecahan masalah ini dengan menggunakan pendekatan kualitatif. Pendekatan penelitian kualitatif disebut juga "pendekatan naturalistik karena situasi lapangan penelitian bersifat natural atau alamiah apa adanya, dan tidak manipulasi" (Cresswel, 1998; Nasution, 1996). Dalam penelitian ini, diharapkan peneliti dapat memperoleh informasi dan data yang akurat mengenai penelitian. Sesuai dengan pendapat Strauss dan Corbin (2009, hlm. 4) dalam Rohani (2013, hlm. 79) pendekatan kualitatif yaitu suatu pendekatan yang temuan-temuannya tidak diperoleh melalui prosedur statistik atau bentuk hitungan lainnya, melainkan lebih menekankan kepada kajian interpretatif. Pendekatan kualitatif yang digunakan dalam penelitian ini berimplikasi pada penggunaan ukuran-ukuran kualitatif secara konsisten, artinya dalam pengolahan data, sejak mereduksi, menyajikan, memferifikasi dan menyimpulkan data tidak menggunakan perhitungan-perhitungan secara matematis dan statistik, melainkan lebih menekankan pada kajian interpretatif. Sedangkan Metode yang akan digunakan dalam penelitian ini adalah studi kasus (Case Study) yang merupakan bagian dari penelitian kualitatif. Creswell (2010, hlm. 20) mengemukakan bahwa metode penelitian kualitatif juga meliputi sejumlah metode penelitian, antara lain penelitian Etnografi, Grounded Theory, Studi Kasus, Fenomenologi Dan Naratif. Melalui penelitian studi kasus diharapkan peneliti dapat menyelidiki secara cermat suatu program, peristiwa, aktivitas proses dan kelompok individu berdasarkan prosedur pengumpulan data yang telah ditentukan mengenai pengembangan kesadaran demokrasi di organisasi Badan Eksekutif Mahasiswa Universitas Pasir Pengaraian.

\section{Partisipan Penelitian}

Dalam kaitannya penetapan Partisipan Penelitian, maka ada beberapa kriteria yang digunakan yaitu “latar (setting), para pelaku (actors), peristiwa-peristiwa (events), dan proses (process)' (Miles dan Huberman, 2007). Berdasarkan hakikat dalam penelitian kualitatif, maka subjek dalam penelitian ini ditentukan secara snow ball sampling, artinya subjek penelitian relatif sedikit dan dipilih menurut tujuan penelitian, namun subjek penelitian dapat terus bertambah sesuai keperluannya. Sesuai dengan yang dikemukakan oleh Bogdan \& Biklen (1982), Nasution (1992) dalam Miles \& Huberman (2007). Adapun Partisipan Penelitian adalah Staf Ahli Kemahasiswaan, Pembina Kemahasiswaan, Presiden BEM, Wakil Presiden BEM dan Kementrian BEM yang berjumlah 10 Partisipan. Penelitian ini, menentukan jumlah partisipan dengan menggunakan teknik Snow Ball Sampling dalam pengumpulan datanya. Apabila dalam pengumpulan datanya tidak cukup hanya dari satu sumber, maka dikumpulkan juga data dari sumbersumber lainnya.

\section{Tempat Penelitian}

Lokasi penelitian merupakan tepat penelitian yang akan dikumpulkan mengenai suatu peristiwa dan berbagai informasi terkait dengan tempat, pelaku dan kegiatan. Menurut Nasution, S. (2003, hlm. 43), lokasi penelitian adalah lokasi situasi yang mengandung tiga unsur, yakni: tempat, pelaku dan kegiatan. Sesuai dengan masalah dalam penelitian ini, maka lokasi penelitian yang dimaksudkan adalah Badan Eksekutif Mahasiswa (BEM) Universitas Pasir Pengaraian. Karena pada dasarnya BEM Universitas Pasir 
Pengaraian, merupakan oraganisasi mahasiswa intra kampus yang didalamnya terjadi suatu peristiwa dan kegiatan organisasi.

\section{Teknik Pengumpulan Data}

Dalam peneltian kualitiatif, pengumpulan data dilakukan di dalam "natural setting" (kondisi yang alamiah), sumber data primer, dan teknik pengumpulan data yang banyak kepada observasi pada mahasiswa BEM serta mengamati tahapan-tahapan yang dilalui, observasi partisipatif, wawancara, dokumentasi, dan triangulasi. Sesuai dengan pendapat Marshall, et.al (Sugiyono, 2011, hlm. 225) menyatakan bahwa "the fundamental methods relied on by qualitative researchers for gathering information are, participation in the setting, direct observation, in-depth interviewing, document review". Sehingga dapat disimpulkan bahwa dalam penelitian kualitatif alat pengumpul data yang digunakan yaitu observasi partisipatif, wawancara mendalam, dokumentasi, dan gabungan/triangulasi. Namun dalam penelitian ini, peneliti menggunakan teknik pengumpulan data berupa observasi, wawancara, dokumentasi, dan triangulasi.

\section{Teknik Analisis Data}

Analisis data dilakukan dalam suatu proses, proses berarti pelaksanaannya sudah mulai dilakukan sejak pengumpulan data dan dilakukan secara intensif, yakni sesudah meninggalkan lapangan, pekerjaan menganalisis data memerlukan usaha pemusatan perhatian dan pengarahan tenaga fisik dan pikiran dari peneliti, dan selain menganalisis data peneliti juga perlu mendalami kepustakaan guna mengkonfirmasikan teori baru yang barangkali ditemukan. Dalam penelitian ini analisis data mengacu pada langkah-langkah yang dipakai oleh Miles dan Huberman (2007) yang terdiri atas tiga alur kegiatan yang terjadi secara bersamaan, yaitu: reduksi data, penyajian data, dan penarikan kesimpulan atau verifikasi. Analisis data kualitatif merupakan upaya yang berlanjut, berulang dan terus menerus. Langkahlangkah yan digunakan meliputi reduksi data, penyajian data, dan penarikan kesimpulan merupakan rangkaian kegiatan analisis yang saling susul menyusul.

\section{HASIL DAN PEMBAHASAN \\ Kondisi Kesadaran Demokrasi dalam Organisasi Badan Eksekutif Mahasiswa (BEM) Universitas Pasir Pengaraian}

Pembentukan organisasi kemahasiswaan di Universitas Pasir Pengaraian mendapat legalitas yang memberikan kebebasan kepada mahasiswa untuk membentuk organisasi di kampusnya, yang mana hal tersebut merupakan salah satu aspek untuk membentuk karakter mahasiswa yang demokratis. Sejalan dengan dikeluarkan Keputusan Menteri Pendidikan Nasional Nomor 155/U/1998 tentang Pedoman Umum Organisasi Kemahasiswaan bahwa organisasi kemahasiswaan di perguruan tinggi diselenggarakan berdasarkan prinsip dari, oleh dan untuk mahasiswa dengan memberikan peranan dan keleluasaan lebih besar kepada mahasiswa. berdasarkan Kepmendikbud inilah Universitas Pasir Pengaraian Membentuk organisasi kemahasiswaan dalam hal ini secara legalitas yang sah memberikan kebebasan kepada mahasiswa untuk membentuk organisasi di kampus. Hal tersebut merupakan salah satu aspek untuk membentuk karakter mahasiswa yang demokratis. Bahwa dalam implementasinya konsep dan nilai demokrasi, menurut Dahl (1988) dalam Suyatno (2008) bahwa ada beberapa prasyarat yang harus dipenuhi negara untuk mewujudkan demokrasi yakni : (1) adanya kebebasan untuk membentuk dan mengikuti organisasi; (2) adanya kebebasan mengeluarkan pendapat; (3) kebebasan memilih dalam pemilu; (4) hak menduduki jabatan publik; (5) hak para pemimpin untuk bersaing memperoleh dukungan dan suara rakyat; (6) tersedianya sumber-sumber informasi alternatif; (7) adanya pemilu yang bebas dan adil; (8) adanya lembaga-lembaga untuk menjadikan kebijakan pemerintah tergantung pada suara dalam pemilu dan ekspresi pilihan lainnya. Oleh karena itu, konsep demkrasi di organisasi BEM Universitas Pasir Pengaraian yang menjadi kriteria terlaksanaanya demokrasi meliputi terciptanya suasana kebebasan berorganisasi bagi mahasiswa, kebebasan berpendapat bagi setiap pengurus dan terbukanya kesempatan bagi setiap pengurus untuk menduduki jabatan dalam organisasi BEM.

Sebagai insan akademis mahasiswa dituntut untuk terus berupaya mengembangkan diri untuk menjadi bagian dari struktur masyarakat masa depan yang berkualitas. Pendidikan merupakan insrtrumen pendidikan demokrasi yang sangat penting, baik aspek konseptual, maupun penerapan. Untuk itu, kesadaran berdemokrasi harus digali dalam sebuah organisasi, sebab organisasi adalah wadah mahasiswa mengembangkan prilaku berdemokrasi dan selanjutnya dikembangkan dalam kehidupan masyarakat berbangsa dan bernegara. Senada dengan pendapat ini Muhamad (2000) mengatakan organisasi adalah suatu koordinasi rasional kegiatan sejumlah orang untuk mencapai beberapa tujuan umum melalui 
pembagian pekerjaan dan fungsi melalui hierarki otoritas dan tanggungjawab. Budaya demokrasi yang dikalangan mahasiswa perilaku yang dapat diamati dalam bentuk interaksi antar mahasiswa dalam berorganisasi, meliputi kegiatan yang berkenanan dengan proses kegiatan pembuatan dan pelaksanaan kepetusan dalam organisasi mahasiswa dalam menyoroti perilaku demokrasi dalam berorganisasi.

Berkaitan dengan pernyataan tersebut di atas bahwa perilaku demokrasi dalam organisasi merupakan bentuk pilihan dan kesadaran akan hak individu yang hidup sebuah organisasi yang pastinya memiliki sistem tertentu. Sistem memiliki berbagai komponen yang saling berkaitan dan mempunyai tujuan dan fungsi yang sama. Untuk mencapai tujuan tersebut, maka semua komponen harus bekerjasama dan saling memfungsikan diri untuk sama-sama mencapai tujuan yang diinginkan. Dengan adanya faham tersebut mahasiswa sebagai golongan akademisi yang senantiasa berserikat dan berkumpul dalam suatu wadah organisasi kemahasiswaan menerapkan sistem tersebut dalam organisasi mahasiswa (Ormawa). Organisasi kemahasiswaan harus mampu membentuk sosok utuh mahasiswa. Oleh karena itu organisasi kemahasiswaan harus mewadahi wujud identitas dan aktualisasi peran mahasiswa. Berdasarkan konsepsi organisasi kemahasiswaan diatas, maka secara umum orientasi organisasi mahasiswa dapat sebagai wadah pengembangan diri mahasiswa untuk membentuk lapisan masyarakat masa depan yang Profesional, Intelek, Humanis, dan Religius, sebagai wadah karya mahasiswa dan wadah bagi upaya pemenuhan kebutuhan dasar mahasiswa yang meliputi pendidikan, kesejahteraan, dan aktualisasi diri mahasiswa.

Penerapan sistem demokrasi dalam organisasi kemahasiswaan sudah berjalan, hal tersebut tercermin dengan adanya kebebasan dalam berorganisasi yang setiap mahasiswa memiliki hak dan kewajiban menjalankan organisasi kampus dan harus aktif pada salah satu organisasi kampus meliputi Hima Prodi, BEM Fakultas, BEM Universitas dan UKM yang ada di Universitas Pasir Pengaraian. Sehingga perlu pembagian kekuasaan dalam pemerintahan mahasiswa, pemilihan ketua atau pimpinan organisasi yang dilakukan secara langsung, serta dengan menyelenggarakan sidang umum atau musyawarah mahasiswa secara bebas untuk menyatakan penadapatnya serta menghormati dan menghargai pendapat orang lain. Oleh sebab itu, untuk mencapai tujuan yang sama dalam berorganisasi harus dijembatani dengan saling kerja sama. Pentingnya kerjasama yang dibangaun diperlukan untuk mengatasi persoalan yang muncul dan kenadala yang diahadapi mahasiswa yang berhubungan dengan perkuliahan. Kerjasama yang dimaksud disini adalah kerjasama dalam hal yang berhubungan dengan kepentingan mahasiswa. Kerja sama sangat bermanfaat dalam nmenyelesaikan berbagai permalahan yang dihadapi, dan pengurus terkesan kompak dalam berbagai situasi. Kerjasama yang baik terjalin dalam sebuah kepengurusan. Sehingga kerjasama yang terbangun antar pengurus juga memberikan kontribusi besar terhadap kelancaran berbagai kegiatan yang dilakukan oleh BEM.

Pada dasarnya kebebasan dalam berorganisasi ini merupakan wadah menunjukkan kesadaran dalam bersikap dan berperilaku yang demokratis dalam tataran sistem pemerintahan mahasiswa. Hal ini ditandai dengan adanya sebuah ruang kebebasan untuk menyampaikan pendapat bagi para pengurus dalam forum rapat kerja. Kebebasan menyampaikan pendapat merupakan sebuah hak dasar yang miliki oleh setiap pengurus BEM Universitas Pasir Pengaraian yang senantiasa di berikan kesempatan dan ruang, baik secara lisan dan tulisan. Kesempatan menyampaikan pendapat tidak pernah menadapat batasan, terutama berkaitan dengan kepentingan organisasi dan selama itu berkaitan dengan kepentingan mahasiswa secara umumnya. Konsep egalitar dan persamaan kesempatan dalam berorganisasi mahasiswa dikampus merupakan asas persamaan kesempatan dalam memperoleh kesempatan pengembangan pengetahuan dan kesempatan untuk memperoleh pengetahuan dalam berorganisasi. Kesempatan yang sama antar pengurus dalam melakukan berbagai kegiatan dan kontribusi dalam pemikiran. Kesetaraan itu berupa adanya kesempatan yang sama bagi setiap pengusrus tanpa membedakan etnis, bahasa, daerah maupun agama dengan memberikan kesempatan yang seluas-luasnya kepada pengurus untuk terlibat dalam kepengurusan dengan tidak memandang latar belakang seseorang.

Oleh karenanya, dengan adanya sebuah nilai saling percaya yang ditanamkan kepada setiap anggota. Rasa percaya yang dimiliki di tunjukkan melalui sikap dan tindakan tidak ada saling curuga. Kepercayaan antar sesama anggota menunjukan sebuah perembangan yang positif, seiring dengan meningkatnya kebebasan berpartisipasi yang dimiliki oleh setiap pengurus BEM selama ini terlihat sangat baik dari keberhasilan BEM menjalankan kegiatan - kegiatan intrakulikuler dan ekstrakulikuler. Jadi dapat disimpulkan bahwa kondisi kesadaran demokrasi BEM Universitas Pasir Pengaraian sudah memiliki kesadaran demokrasi yang baik, hal itu terlihat pada penerapan sistem demokrasi yang ada di organisasi mahasiswa terlihat melalui adanya kebebasan dalam berorganisasi dan terjalin kerja sama bagi pengurus, adanya kesempatan dalam mengemukakan pendapat oleh pengurus, adanya rasa saling percaya dan sikap saling menghargai, ada prisip persamaan kedudukan di dalam organisasi mahasiswa. 


\section{Proses Peningkatan Kesadaran Demokrasi dalam Organisasi Badan Eksekutif Mahasiswa (BEM) Universitas Pasir Pengaraian}

Dewasa ini masyarakat sangat mendambakan generasi mudanya dipersiapkan untuk menjadi warganegara yang baik (Good Citizenship) dan dapat berpartisipasi dalam kehidupan masyarakat dan negaranya. Keinginan tersebut lebih tepat disebut sebagai perhatian yang terus tumbuh, terutama dalam masyarakat demokratis yang telah mencapai tingkat pemahaman dan penerimaan terhadap hak-hak dan tanggung jawab di antara keseluruhan warganegara untuk menyokong kehidupan demokrasi. Berkaitan dengan pengembangan kesadaran akan nilai-nilai demokrasi tersebut di atas, diperlukan pendidikan demokrasi dalam tatanan social kemasyarakatan atau domain akademik. Pendidikan demokrasi menurut Winataputra dan Budimansyah, (2007) adalah upaya sistematis yang dilakukan negara dan masyarakat untuk menfasilitasi individu warga negara agar memahami, menghayati, mengamalkan, dan mengembangkan konsep, prinsip, dan nilai demokrasi sesuai dengan status dan perannya dalam masyarakat. Menurut Kingsbury dalam Fachrudin (2006, hlm. 4), pendidikan kewarganegaraan demokratis untuk masyarakat Indonesia telah dilaksanakan dalam berbagai bentuk, melalui pendidikan formal (School-Based Democracy Education) atau pun Community-Based Democracy Education, yang dilaksanakan dalam masyarakat. Selama orde pemerintahan Soekarno, pendidikan demokrasi dititikberatkan pada konsep "Bhineka Tunggal lka", satu bahasa nasional (Indonesia), semangat antiimperalisme, dan kesetiaan kepada bangsa dan Negara.

Menurut Winataputra (2001) Visi pendidikan demokrasi adalah sebagai wahana substantif, pedagogis, sosial-kultural untuk membangun cita-cita, nilai, konsep, prinsip, sikap, dan keterampilan demokrasi dalam diri warga negara melalui pengalaman hidup dan berkehidupan demokrasi dalam berbagai konteks. Dengan wawasan dan pengalamannya itu, baik secara sendiri-sendiri maupun bersamasama warga nagara mampu memberikan kontribusi yang bermakna bagi peningkatan kualitas demokrasi dalam bermasyarakat berbangsa dan bernegara Indonesia. Inilah makna dari "learning democracy, through democracy, and for democracy". Menunjuk kepada visi dan misi tersebut di atas, maka pendidikan demokrasi sangat penting dikembangkan dalam kontkes social kemasyarakatan atau dalam konteks akademik dengan mengembangkan strategi atau pendekatan yang seyogyanya harus dilakukan, baik melalui pemanfaat media social, lingkungan sebagai sumber dan maupun melakukan penelitian social dan aksi social yang mengedepankan budaya berdemokrasi.

Budaya demokrasi adalah hasil dari suatu proses dimana setiap manusia memiliki pemikiran dan kemampuan melakukan tindakan politik yang didasarkan pada penghargaan terhadap persamaan hak, kebebasan, keteraturan bersama dan keragaman. Tanpa adanya kesadaran dan komitmen yang benar dari warganegara terhadap nilai dan prinsip fundamental demokrasi, maka masyarakat yang terbuka dan bebas, tak mungkin terwujud. Berkaitan dengan hal tersebut, menurut May (Koswara, 1987: 51) dalam Yuniarto, B (2013, hlm. 18) mengatakan kesadaran merupakan Kesadaran diri sebagai kapasitas yang memungkinkan manusia mampu mengamati dirinya sendiri maupun membedakan diri dari dunia orang lain serta kapasitas yang memungkinkan manusia menempatkan diri dalam waktu kini, masa lampau dan masa yang akan datang. Dari pendapat tersebut di atas dapat dikatakan bahwa kesadaran seseorang dapat berimplikasi terhadap cara pandang seseorang berkaitan dengan dirinya maupun dengan sekitarnya. Maka dari itu untuk meningkatkan kesadaran demokrasi mahasiswa BEM Universitas Pasir Pengaraian, Pembina kemahasiswaan harus melakukan pendekatan persuasif ke seluruh Pengurus BEM dan UKM seperti musyawarah, dialog dan diskusi dalam setiap kegiatan yang akan dilaksanakan oleh mahasiswa khususnya BEM, supaya setiap kegiatan yang dilakukan searah dengan Visi Misi Universitas Pasir Pengaraian.

Kepedulian yang ditanamkan oleh Pembina kemahasiswaan dapat memupuk kesadaran mahasiswa supaya bisa menganggapi sesuatu hal tertentu dengan didasari dengan pengertian, pemahaman, penghayatan, dan pertimbangan nalar dan moral dengan disertai kebebasan sehingga dapat mempertangung jawabkannya secara sadar setiap kegiatan yang terlaksana dan tidak melakukan kegiatankegiatan yang arogansi seperti mendemo tanpa arah yang dapat merugikan institusi kampus serta melakukan pemilihan umum yang bersih, adil dan bekesinambungan dengan tetap diberikan kebebasan untuk berasosiasi bagi setiap warganegara atau anggota organisasi. Strategi ini memberikan keleluasaan kepada pengurus untuk mengikuti organisasi baik itu organisasi kampus maupun organisasi di luar kampus, sehingga pegurus mendapatkan pengalaman organisasi yang lebih matang. Senada dengan pernyataan tersebut, bahwa dalam implementasinya konsep dan nilai demokrasi, menurut Dahl dalam Suyatno (2008) bahwa ada beberapa prasyarat yang harus dipenuhi negara untuk mewujudkan demokrasi (polyarchy), yakni : (1) adanya kebebasan untuk membentuk dan mengikuti organisasi; (2) adanya kebebasan mengeluarkan pendapat; (3) kebebasan memilih dalam pemilu; (4) hak menduduki jabatan 
publik; (5) hak para pemimpin untuk bersaing memperoleh dukungan dan suara rakyat; (6) tersedianya sumber-sumber informasi alternatif; (7) adanya pemilu yang bebas dan adil; (8) adanya lembaga-lembaga untuk menjadikan kebijakan pemerintah tergantung pada suara dalam pemilu dan ekspresi pilihan lainnya.

Oleh sebab itu, untuk mencapai peningkatan kesadaran demokrasi mahasiswa harus dibarengi dengan kegiatan - kegiatan penalaran yang sifatnya ilmiah dan pembiasaan yang dilakukan mahasiswa agar pengurus BEM memiliki kesadaran demokrasi yang baik sesuai dengan nilai-nilai demokrasi yang tardapat dalam sistem demokrasi dalam menjalan sebuah organisasi. Setiap mahasiswa baru akan mendapatkan penalaran dunia kampus pada saat PKKMB yang dilaksanakan Universitas setiap tahunnya seperti Kuliah Umum, Perkenalan Kampus dan Pelatihan Kepemimpinan yang bertujuan untuk melatih kemampuan berorganiasasi mahasiswa baru. Sedangkan bagi mahasiswa yang sudah menjadi bagian dari kepengurusan BEM dan UKM setiap tahunnya melakukan seminar - seminar dan kegiatan keakraban guna menambah wawasan mahasiswa dan meningkatkan kesadaran atau kepedulian mahasiswa terhadap kampus Universitas Pasir Pengaraian.

Kegiatan yang dilakukan oleh BEM dalam rangka peningkatan demokrasi seperti pengkaderan dan pelatihan. Kegiatan utama yang dilakukan ialah berusaha bersikap demokratis di dalam sebuh forum diskusi, dengan tidak memaksakan pendapat mereka. Selain itu juga BEM melakukan kegiatan pelatihan kepemimpinan yang secara rutin dilakukan setiap tahun. Upaya yang BEM dilakukan itu dalam bentuk latihan kepemimpnan, training legeslatif dan eksekutif. Namun dalam hal ini dalam proses melakukan kegiatan dan sosilaisi jangan sampai mengumpulkan dana dari mahasiswa. Kegiatan pelatihan kepemimpinan dan organisasi yang dilakukan untuk membentuk kader yang displin dan penuh tanggung jawab serta menambah kemampuan yang mahasiswa dapatkan di kelas dengan memberikan pengetahuan tentang organisasi mahasiswa sebagai penunjang pengembangan kepribadian, minat dan bakat. Kegiatan pelatihan kepemimpinan sangat memberikan pengalaman yang bermakna bagi pengurus terutama untuk menciptakan semangat Lidership yang dipersiapkan untuk mejadi pemimpin. Walaupun bahwa sejauh ini tidak menutup kemingkinan terjadi sebuah perbedaan pemikiran antar sesama pengurus, namun semuanya bisa di komunikasi secara baik di tubuh organisasi.

Selain itu, dalam upaya meningkatkan dan menciptakan generasi muda yang berprestasi, kreasi, intelek, dan beriman untuk membangun bangsa dan negara kita serta siap menghadapi globalisasi. Kegiatan yang dilakukan BEM FKIP seperti Olimpiade setiap tahunnya merupakan kegiatan penalaran yang dapat menambahkan wawasan mahasiswa dalam setiap rangkaian kegiatan seperti menyusun acara, membuat soal dan aktif dalam menyelenggarakan Olimpiade tersebut sehingga mahasiswa kedepannya bisa menyalurkan bakat menjadi guru profesional dalam mendidik siswanya untuk kompetitif setingkat Olimpiade. Maka, Pembinaan yang yang dilakukan tersebut memberikan sebuah pengaruh yang positif terhadap kinarja BEM. Strategi yang digunakan tersebut efektif dalam menberikan pengalam organisasi kepada mahasiswa dan juga dapat mengembangkan kesadaran demokrasi kepengurusan BEM sekarang ini. Kegiatan yang dilakukan itu juga memberikan pengaruh yang positif terhadap kesadaran demokrasi mahasiswa yakni meningkatnya kebebasan berpartisipasi pengurus, kebebasan berpendapat, meningkatnya rasa saling percaya, kerja sama yang semakin solit dalam kepengurusan dan juga meningkatnya keberhasilan berbagai kegiatan yang dilakukan yang di agendakan.

\section{SIMPULAN}

Berdasarkan Hasil Penelitian yang telah diuraikan diatas dapat kita ketahui bahwa kondisi kesadaran demokrasi BEM mahasiswa Universitas Pasir Pengaraian sudah berjalan sesuai dengan nilainilai demokrasi, hal ini tercermin dengan adanya kebebasan dalam berorganisasi seperti memilih dan dipilih dalam pemilihan umum, menjadi anggota pengurus BEM serta dengan menyelenggarakan sidang umum atau musyawarah mahasiswa secara bebas untuk menyatakan penadapatnya serta menghormati dan menghargai pendapat orang lain. Kesadaran akan berdemokrasi mahasiswa dalam sebuah organisasi terwujud dalam dalam perilaku dalam konteks organisasi BEM yang sesuai aturan yang berlaku. Sehingga kesadaran tersebut meliputi menumbuhkan sikap kerja sama bagi pengurus, adanya kesempatan dalam mengemukakan pendapat oleh pengurus, adanya rasa saling percaya dan sikap saling menghargai, ada prisip persamaan kedudukan di dalam organisasi mahasiswa dapat sebagai wadah pengembangan diri mahasiswa untuk membentuk lapisan masyarakat masa depan yang Profesional, Intelek, Humanis, dan Religius, sebagai wadah karya mahasiswa dan wadah bagi upaya pemenuhan kebutuhan dasar mahasiswa yang meliputi pendidikan, kesejahteraan, dan aktualisasi diri mahasiswa.

Kepedulian yang ditanamkan oleh Pembina kemahasiswaan guna melakukan pendekatan persuasif dapat memupuk kesadaran mahasiswa supaya bisa menganggapi sesuatu hal tertentu dengan didasari dengan pengertian, pemahaman, penghayatan, dan pertimbangan nalar dan moral dengan disertai kebebasan sehingga dapat mempertangung jawabkannya dalam melaksanakan kegiatan - kegiatan yang 
sifatnya penalaran dan pembiasaan yang dilakukan mahasiswa agar pengurus BEM memiliki kesadaran demokrasi yang baik sesuai dengan nilai-nilai demokrasi yang tardapat dalam sistem demokrasi dalam menjalan sebuah organisasi. Setiap mahasiswa baru akan mendapatkan penalaran dunia kampus pada saat PKKMB yang dilaksanakan Universitas setiap tahunnya seperti Kuliah Umum, Perkenalan Kampus, Seminar Nasional dan Pelatihan Kepemimpinan yang bertujuan untuk melatih kemampuan berorganiasasi mahasiswa baru serta kegiatan pelatihan kepemimpinan sangat memberikan pengalaman yang bermakna bagi pengurus terutama untuk menciptakan semangat Lidership yang dipersiapkan untuk mejadi pemimpin. Kegiatan yang dilakukan itu juga memberikan pengaruh yang positif terhadap kesadaran demokrasi mahasiswa menambah wawasan dan meningkatkan kesadaran atau kepedulian mahasiswa terhadap kampus Universitas Pasir Pengaraian.

\section{DAFTAR PUSTAKA}

Candra C, (2012), Pendidikan Kewarganegaraan Sebagai Wahana Pendidikan Multikultural Dalam Membangun Kesadaran Demokrasi Warga Negara, Bandung: UPI Unpublise.

Cresswell, J.W. (2010). Research Design (Pendekatan Kualitatif, Kuantitatif, dan Mixed); Cetakan ketiga. Yokyakarta: Pustaka Belajar.

Djahiri, A.K. (1985). Strategi pembelajaran afektif nilai moral VCT dan games dalam VCT. Bandung: Jurusan PKN FIPS UPI.

Fachrudin, F. (2006). Agama dan Pendidikan Demokrasi: Pengalaman Muhammadiyah dan NU. Jakarta: PT Alvabeta.

Miles, M.B. \& Huberman, A. M. (2007). Analisis Data Kualitatif: Buku Sumber tentang Metode-metode Baru. Terjemahan oleh Tjetjep Rohendi Rohidi dan judul Qualitative Data Anlysis. Jakarta: Universitas Indonesia Press.

Muhammad, A. (2000). Komunikasi Organisasi. Jakarta: Bumi Aksara.

Nasution, S. (1996). Metode Riset, Bandung: Jermmous.

Nasution. (1996). Metode Penelitian Naturalistik Kualitatif. Bandung: PT Tarsito.

Rapoport, A. (2008), A Forgotten Concept: Global Citizenship Education and State Social Studies Standards. The Journal Of Social Studies Research, 33 (I), 91-112.

Rohani. (2012), Pembinaan Tanggung Jawab Warga Negara Dalam Memecahkan Masalah-masalah Sosial Melalui Pendidikan Kewarganegaraan kemasyarakatan (Community Civics), Bandung: UPI Unpublise.

Sapriya dan Winataputra (2010), Materi dan Pembelajaran PKn. Jakarta: UT.

Sugiyono. (2012). Metode Penelitian Pendidikan (Pendekatan Kuantitatif, Kuahtatf dan R\&D). Bandung: Alfabeta.

Suyatno. (2008). Menjelajahi Demokrasi. Bandung: PT Humaniora.

Wahab, A \& Sapriya. (2011). Teori dan Landasan Pendidikan Kewarganegaraan. Bandung: Alfabeta.

Winataputra, U.S. (2001). Jatidiri Pendidikan Kewarganegaraan Sebagai Wahana Sistemik Pendidikan Demokrasi. Ringkasan Desertasi Doktor Pada FPS UPI Bandung: tidak diterbitkan.

Winataputra, U.S dan Budimansyah, D. (2007). Civic Education: Konteks, Landasan, Bahan Ajar dan Kultur Kelas. Bandung: Prodi PKn SPS UPI.

Yuniarto, Bambang. (2013). Membangun Kesadaran Warga Negara Dalam Pelestarian Lingkungan. Yogyakarta: Deepublish.

Kemendikbud. Nomor 155 tahun 1998 tentang Pedoman Umum Organisasi Kemahasiswaan.

Direktorat Jenral Pendidikan Tinggi. (2006). Polbangmawa (Pola Pengembangan Mahasiswa). Jakarta: Depdiknas.

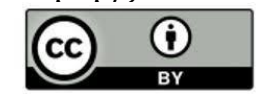

